\title{
STRATEGI PRODI MANAJEMEN KEUANGAN SYARIAH DALAM MENGEMBANGKAN MINAT MAHASISWA BERWIRAUSAHA
}

\author{
Marhaban \\ Dosen Institut Agama Islam Negeri Langsa \\ Hajimarhaban1705@yahoo.com
}

\begin{abstract}
The development of entrepreneurship spirit has become a crucial things for the future of students. In supporting the emergence of high competitiveness, function and role of educators to be more active in providing motivation for learners to become entrepreneurs is indispensable. College as one of the means and facilitating role in shaping the young generation has an obligation to train and motivate the students to be come savvy generation, independent, creative, innovative and able to create business opportunities. Thus, every college immediately towards sole discreation to balance between higher education research institutions with entrepreneurs forming institutions. Alumni are required to be innovative and creative in terms of their personal development through the creation of level playing field, so that future expected with extensive job creation, economic growth in the region will increase.The aims of this study is to analyze the strategic of program study of law economic syariah should do to improve the interest of being entrepreneur of student.
\end{abstract}

Keywords: Shariah Financial Management, the strategic of program study of law economic syariah and Entrepreneurs.

\begin{abstract}
Abstrak
Perkembangan semangat kewiraswastaan telah menjadi hal yang krusial bagi masa depan mahasiswa. Dalam mendukung munculnya daya saing, fungsi dan peran pendidik yang tinggi agar lebih aktif dalam memberikan motivasi bagi peserta didik untuk menjadi pengusaha sangat diperlukan. Perguruan tinggi sebagai salah satu sarana dan fasilitasi yang berperan dalam membentuk generasi muda berkewajiban untuk melatih dan memotivasi para mahasiswa untuk menjadi generasi penerus, mandiri, kreatif, inovatif dan mampu menciptakan peluang bisnis. Dengan demikian, setiap perguruan tinggi langsung menuju satu pertimbangan untuk menyeimbangkan antara lembaga penelitian pendidikan tinggi dengan pengusaha membentuk institusi. Alumni
\end{abstract}


dituntut untuk inovatif dan kreatif dalam hal pengembangan pribadi mereka melalui penciptaan lapangan baru, sehingga diharapkan masa depan dengan penciptaan lapangan kerja yang luas, pertumbuhan ekonomi akan semakin meningkat. Tujuan dari penelitian ini adalah untuk menganalisis strategi Program studi hukum ekonomi syariah dalam meningkatkan minat menjadi wirausahawan.

Kata Kunci : Manajemen Keuangan Syariah, Strategi program studi Hukum Ekonomi syariah dan Wirausaha.

\section{PENDAHULUAN}

Permasalahan pengangguran merupakan permasalahan besar nasional yang perlu dipecahkan secara terpadu dan sinergi oleh semua instansi dan lembaga pemerintah, dunia usaha dan komponen masyarakat lain yang perduli. Tingginya angka pengangguran dan sangat terbatasnya lapangan kerja yang ada, nampaknya belum mampu menyadarkan dan menggugah (belum mendapat perhatian serius, sering, sering dilupakan, dan harus mendapat perhatian) mahasiswa, dosen dan segenap pimpinan perguruan tinggi untuk merubah orientasinya. Hasil analisis data yang dipublikasikan Dirjen Dikti Depdiknas RI pada banyak kesempatan menunjukkan, bahwa semakin tingginya tingkat pendidikan di Indonesia ternyata tidak secara linier berdampak terhadap peningkatan kesejahteraan dan ekonomi. Lebih jauh dari itu, ternyata semakin tinggi tingkat pendidikan seseorang di Indonesia, semakin rendah tingkat kemandirian dan jiwa kewirausahaannya (Kompas.com).

Banyaknya jumlah pengangguran tersebutm termasuk lulusan perguruan tinggi dikarenakan berbagai faktor, diantaranya:

1. Sistem pembelajaran yang diterapkan di perguruan tinggi saat ini lebih terfokus pada bagaimana menyiapkan para mahasiswa yang lebih cepat lulus dan mendapatkan pekerjaan. Sehingga lulusannya lebih bertindak 
sebagai pencari kerja (job seekers) ketimbang membuka lapangan pekerjaan (job creators) bagi orang lain;

2. Masalah link and match antara lulusan perguruan tinggi dengan dunia kerja sampai sekarang ini belum terselesaikan dengan baik. Artinya lulusan perguruan tinggi masih dianggap kurang sesuai dengan kebutuhan dunia kerja, terutama oleh kalangan Dunia Usaha dan Dunia Industri (DUDI). Menurut pandangan DUDI, lulusan perguruan tinggi (terutama S1) kurang siap pakai, cukup lama menyesuaikan dengan lingkungan kerjanya (apabila sudah diterima sebagai pegawai);

3. Kondisi seperti tersebut di atas, sebenarnya sebagai akibat dari orientasi kurikulum perguruan tinggi yang dominan pada pencapain indeks prestasi akademik (IPK) dan penyelesaian masa studi, sedangkan kompetensi lain misalnya bidang keterampilan (life skills), softskill, dan kewirausahaan belum banyak dikembangkan. Pembinaan potensi mahasiswa selama di kampus lebih dominan mengembangkan aspek kognitif, bakat dan minat dengan tujuan terbatas untuk kepentingan mengisi waktu luang. Ada kecenderungan mahasiswa dalam kegiatan ekstra kampusnya lebih terfokus kepada hal-hal bidang politik ketimbang hal-hal bidang ekonomi atau kewirausahaan;

4. Dari sisi demand tenaga kerja, yaitu dunia usaha dan industry sebagai end user, daya serapnya hanya mencapai $10 \%$ sampai $15 \%$, sehingga setiap tahun terjadi peningkatan jumlah angkatan kerja yang tetap terserap. Akibatnya jumlah pengangguran, terutama dari kalangan intelektual terus mengalami peningkatan.

Indikasi dari realitas tersebut adalah banyaknya lulusan yang walaupun berpengetahuan tinggi tetap kurang mampu menyejahterakan diri dan lingkungannya. Oleh karenanya pendidikan tinggi di Indonesia perlu lebih menyiapkan lulusannya menjadi sarjana yang mampu hidup mandiri, berkreasi, memanfaatkan sains, dan teknologi serta seni yang telah dipelajarinya. 
Demikian halnya yang terjadi pada Fakultas Ekonomi dan Bisnis Prodi Manajemen Keuangan Syariah IAIN Langsa, mental dan orientasi hampir seluruh mahasiswa dan lulusannya bercita cita menjadi PNS dan pegawai saja. Padahal jumlah lulusannya semakin banyak, sedangkan formasi yang tersedia untuk itu, semakin lama semakin sempit.

Oleh karena itu, pemerintah mengharapkan para sarjana yang baru lulus mempunyai kemampuan dan keberanian untuk mendirikan bisnis baru meskipun secara ukuran bisnis termasuk kecil tetapi membuka kesempatan pekerjaan bagi banyak orang. Pihak perguruan tinggi bertanggungjawab dalam mendidik dan memberikan kemampuan dalam melihat peluang bisnis, mengelola bisnis, dan memberikan motivasi untuk mempunyai keberanian menghadapi resiko bisnis. Peran Prodi Manajemen Keuangan Syariah dalam memotivasi mahasiswa menjadi wirausaha muda mandiri, merupakan bagian dari salah satu faktor pendorong pertumbuhan kewirausahaan.

\section{Pengertian Kewirausahaan}

Kewirausahaan adalah kemampuan kreatif dan inovatif yang dijadikan dasar, kiat dan sumber daya untuk mencari peluang menuju sukses. Inti dari kewirausahaan adalah kemampun untuk menciptakan sesuatu yang baru dan berbeda melalui berpikir kreatif dan bertindak inovatif untuk menciptakan peluang. Kewirausahaan merupakan proses penciptaan sesuatu yang baru (kreasi baru) dan membuat sesuatu yang berbeda dari yang telah ada (inovasi), tujuannya adalah tercapainya kesejahteraan individu dan nilai tambah bagi masyarakat. Penciptaan sesuatu yang baru tidak harus benarbenar murni dari hasil pemikiran yang baru pula, melainkan dapat diciptakan dari sesuatu yang sudah ada kemudian dibuat menjadi sesuatu yang berbeda dan bernilai. Sehingga hasil penciptaan tersebut dapat menjadi nilai tambah bagi masyarakat, yaitu menambah penghasilan, keterampilan, dan karya serta 
dapat mensejahterakan individu dan masyarakat tersebut (Yuyus Suryana \& Kartib Bayu : 2013).

Nilai tambahyang diperoleh dan kesejahteraan yang telah tercapai tersebut dapat terus mendorong masyarakat untuk menciptakan sesuatu yang baru dan berbeda. Seperti yang dijelaskan oleh Zimmerer bahwa kewirausahaan adalah suatu proses penerapan kreativitas dan inovasi dalam memecahkan persoalan dan menemukan peluang untuk memperbaiki kehidupan (usaha)( Kasmir : 2011).

Berdasarkan beberapa pendapat tersebut, dapat disimpulkan bahwa kewirausahaan adalah kemampuan untuk menciptakan sesuatu yang baru dan berbeda melalui berpikir kreatif dan bertindak inovatif untuk menciptakan peluang. Menciptakan sesuatu yang kreatif dan bertindak inovatif memiliki arti bhwa dalam penciptaannya dikemas sedemikian rupa dengan kreasi hasil pemikiran yang baru dan berbeda dari apa yang telah ada. Hal ini tentu tidak terlepas dari resiko yang akan didapatkan demi mendapat sebuah keuntungan yang besar.

\section{Pengertian Wirausaha}

Seorang wirausaha adalah seseorang yang menciptakan sesuatu hal dan kegiatan yang berbeda dengan kreatif dan inovatif serta berani mengambil resiko. Sejalan dengan pendapat Leonardo Saiman bahwa wirausaha adalah orang-orang yang memiliki sifat-sifat kewirausahaan dan umumnya memiliki keberanian dalam mengambil resiko terutama dalam menangani usaha atau perusahaannya dengan berpijak pada kemampuan dan kemauan sendiri (Leonardo Saiman : 2014).

Seorang wirausaha dalam menangani usahanya memanfaatkan kemampuan kreativitas dan inovasi serta kemauan yang kuat untuk mencapai suatu keuntungan dan pertumbuhan usahanya dengan mendayagunakan 
sumber-sumber yang ada. Secara sederhana arti wirausahawan (entrepreneur) adalah orang yang berjiwa berani mengambil resiko untuk membuka usaha dalam berbagai kesempatan (Kasmir). Berjiwa berani mengambil resiko artinya bermental mandiri dan berani dalam memulai usaha tanpa diliputi oleh rasa takut dalam kondisi yang tidak menentu. Seorang wirausaha selalu berusaha mencari, memanfaatkan, dan menciptakan peluang usaha yang dapat memberikan keuntungan bagi wirausahawan tersebut.

Para wirausahawan merupakan inovator yang mampu memanfaatkan dan mengubah kesempatan menjadi ide yang dapat dijual atau dipasarkan, memberikan nilai tambah dengan memanfaatkan upaya, waktu, biaya, kecakapan dengan tujuan mendapatkan keuntungan. Resiko kerugian bagi seorang usahawan merupakan hal yang biasa karena mereka memegang prinsip bahwa resiko pasti ada dalam setiap hal yang dilakukan seseorang.

Kesempatan yang diubah menjadi ide dapat berupa penciptaan lapangan pekerjaan maupun produk yang diperlukan oleh masyarakat. Produk tersebut diciptakan oleh para wirausahawan dengan memanfaatkan sumber daya yang ada, kemudian mengolahnya menjadi produk yang memiliki nilai tambah.

Wirausaha mengacu pada orang yang melaksanakan penciptaan kekayaan dan nilai tambah melalui gagasan baru, memadukan sumber daya dan merealisasikan gagasan tersebut menjadi kenyataan. Mekanisme penciptaan kekayaan dan pendistribusian merupakan hal yang mendasar dalam pengembangan usaha (Yuyus Suryana \& Kartib Bayu).

Berdasarkan uraian di atas dapat disimpulkan bahwa wirausaha adalah orang yang mempunyai keberanian mengambil resiko untuk membuka usaha guna mendapatkan keuntungan dengan menggunakan kreativitas mereka. 
Seorang wirausaha akan memanfaatkan sumber daya yang ada untuk dimanfaatkan dan diubah menjadi sesuatu yang baru dalam usahanya.

\section{Sifat dan Kepribadian Wirausaha}

Wirausaha adalah orang yang melihat adanya peluang, kemudian menciptakan sebuah organisasi untuk memanfaatkan peluang tersebut. Seorang wirausaha adalah seseorang yang mampu memandang masa depan dalam artian berpikir dengan berbagai alternatif masalah dan pemecahannya. Berwirausaha tidak cukup dengan membuat produk baru yang kreatif dan inovatif serta berani mengambil resiko. Berdasarkan pengertian tersebut, kepribadian seorang wirausaha diidentifikasikan oleh beberapa peneliti sebagai berikut:

1. Desire for responsibility yaitu memiliki rasa tanggung jawab yang besar terhadap usaha yang baru dirintisnya.

2. Preference for moderate risk. Seorang wirausahawanharus mempertimbangkan resiko dan melihat peluang bisnis berdasarkan pengetahuan, latarbelakang, dan pengalaman mereka.

3. Confidence in their ability to succed. Seorang wirausahawan seringkali memiliki rasa percaya diri yang tinggi sebuah studi yang digelar oleh national federation of independent bussines(NFIB) mengemukakan sepertiga wirausahawan merasa memiliki peluang sukses sebesar $100 \%$.

4. Desire for immediate feedback. Wirausahawan ingin mengetahui bagaimana tanggapan orang lain tentang cara yang mereka sedang jalankan, dan untuk itu mereka senang sekali jika mendapat masukan dari orang lain.

5. High level of energy. Wirausahawan terkesan memiliki energi yang lebih besar dibandingkan dengan kebanyakan orang.

6. Future orientation. Wirausahwan diberkahi kemampuan yang baik dalam melihat sebuah peluang. 
7. Skill at organizing. Usawahan mempunyai kemampuan menempatkan orang sesuai bidang dan kemampuannya.

8. Value of achievement over money. Dalam menjalankan bisnisnya yang menjadi kekuatan utama seorang usahawan adalah sebuah pencapaian kesuksesan, dan uang hanyalah sebuah simbol untuk menandakan sebuah pencapaian (Bambang Banu Siswoyo : 2009).

Menurut Leonardo Saiman, sifat-sifat yang perlu dimiliki wirausaha agar sukses menjadi wirausahawan, yaitu:

1. Berani. Keberanian dalam memutuskan untuk mengubah paradigma bahwa setelah lulus kuliah akan menjadi usahawan atau wirausahawan.

2. Jujur. Jujur kepada mitra atau pemangku kepentigan usaha tersebut (pembeli/pelanggan, pemasok pemerintah, dan atau calon pembeli lainnya).

3. Tekun. Ketekunan merupakan kesadaran dan sifat penting bagi seorang wirausaha, terutama tetap tekun pada saat bisnis mengalami keguncangan.

4. Ulet. Keuletan menjadi modal utama agar tetap tahan banting dan tahan dalam situasi dan kondisi apa pun, kondisi krisis dan atau tidak.

5. Sabar. Kesabaran sering menjadi penentu dalam keberhasilan usaha.

6. Tabah. Ketabahan menjadi penentu bagi seorang pengusaha terutama pada saat usaha mengalami pasang surut.

7. Positif. Sikap dan berpiir positif akan mendorong dan memacu pengusaha untuk meningkatkan usahanya.

8. Rendah hati. Rendah hati akan menjadi modal bagi pengusaha terutama penilaian bagi pihak lain atau mitra usaha.

9. Kemauan (daya juang tinggi). Kemauan atau daya juang tinggi merupakan sikap yang harus dimiliki secara kuat, sebab akan mendorong percepatan usaha tersebut untuk mau maju. 
10.Tanggung jawab. Rasa tanggung jawab yang tinggi atas jenis usaha atau bisnis apa pun yang dimiliki oleh seorang pengusaha akan menata usahanya lebih hati-hati dan penuh tanggung jawab (Leonardo Saiman).

Sifat keberanian dalam berwira usaha merupakan modal utama untuk memulai suatu usaha terutama berani dalam mengambil keputusan bahwa setelah lulus kuliah bukan menjadi pegawai tetapi menjadi wirausahawan. Kejujuran seorang wirausaha merupakan sesuatu yang sangat berharga dan berlaku dimanapun ia berada. Sebab dengan kejujuran yang dimiliki, maka mitra kerja ataupun pelanggan akan setia (loyalitas) kepada wirausahwan tersebut. Ketekunan dan keuletan dalam bisnis atau berwirausaha sangat diperlukan oleh seorang wirausaha agar tetap tahan banting serta tahan dalam kondisi dan situasi apapun, terutama saat usaha yang sedang dijalankan mengalami keguncangan.

Kesabaran dan ketabahan sering menjadi penentu dalam keberlanjutan suatu usaha terutama saat usaha sedang mengalami pasang surut. Orang yang tidak sabar sering mendorong untuk berbuat tidak jujur kepada mitra usaha dengan tujuan untuk memperoleh pendapatan besar dalam jangka pendek dan tidak memikirkan bisnis jangka panjang. Bersikap dan berpikir positif serta bersifat rendah hati akan mendorong pengusaha untuk meningkatkan usahanya. Sifat rendah hati akan mendorong pengusaha untuk meningkatkan usahanya. Sifat rendah hati akan menjadi modal bagi wirausaha terutama dalam hal penilaian bagi mitra usaha bahwa wirausahawan tersebut dapat dijadikan mitra usaha dalam jangka panjang, sebab biasanya orang yang rendah hati akan menyenangkan bagi mitra usaha.

Menjadi wirausahawan yang sukses harus memiliki kemauan atau semangat yang tinggi dalam berwirausaha sebab akan mendorong percepatan dalam memajukan usaha tersebut. Seorang wirausaha harus memiliki rasa tanggung jawab yang tinggi atas usaha yang dimiliki, sebab dengan rasa 
tanggung jawab yang dimilikinya maka ia akan menata usahanya lebih hati-hati dan penuh tanggung jawab terutama bagi mitra usaha dan para staf atau pegawainya.

Selain itu, terdapat sifat-sifat wirausaha yang menjadi ciri khas seorang wirausaha menurut Suryana, yaitu:

1. Percaya diri. Kepercayaan diri akan mempengaruhi gagasan, karsa, inisiatif, kreativitas, ketekunan, semangat kerja, serta kegairahan berkarya.

2. Berorientasi pada tugas dan hasil. Seseorang yang selalu mengutamakan tugas dan hasil adalah orang yang selalu mengutamakan nilai-nilai motif berprestasi, berorientasi pada laba, ketekunan dan kerja keras.

3. Keberanian mengambil resiko. Wirausaha adalah orang yang lebih menyukai usaha-usaha yang lebih menantang untuk mencapai kesuksesan atau kegagalan daripada usaha yang kurang menantang.

4. Kepemimpinan. Seorang wirausaha harus memiliki sifat kepemimpinan, kepeloporan, dan keteladanan.

5. Berorientasi ke masa depan. Wirausaha harus memiliki perspektif dan pandangan ke masa depan. Kuncinya adalah dengan kemampuan untuk menciptakan sesuatu yang baru dan berbeda dari yang sekarang.

6. Keorisinilan: kreativitas dan inovasi. Wirausaha yang kreatif dan inovatif adalah orang yang (a) tidak pernah puas dengan cara-cara yang dilakukan saat ini meskipun cara tersebut cukup baik, (b) selalu menuangkan imajinasi dalam pekerjaannya, dan (c) selalu ingin tampil berbeda atau selalu memanfaatkan perbedaan (Suryana: 2014).

Sifat percaya diri merupakan panduan sifat dan keyakinan seseorang dalam menghadapi pekerjaan, yang bersifat internal, relatif, dan dinamis serta banyak ditentukan oleh kemampuan untuk memulai melaksanakan, dan 
menyelesaikan suatu pekerjaan. Kepercayaan diri akan mempengaruhi gagasan, inisiatif, kreativitas, semangat kerja, ketekunan, dan berkarya. Seorang wirausaha yang berorientasi pada tugas dan hasil, yaitu orang yang selalu mengutamakan nilai-nilai motif berprestasi, berorientasi pada laba, ketekunan, dan bekerja keras.

Seorang wirausaha adalah orng yang lebih menyukai usaha-usaha yang lebih menantang untuk mencapai kesuksesan atau kegagalan daripada usaha yang kurang menantang, sebab hal ini dapat dijadikan suatu pengalaman yang berharga dan dapat diambil sisi positifnya dalam berwirausaha. Kemampuan untuk mengambil resiko tergantung dari keyakinan pada diri sendiri, kesediaan untuk menggunakan kemampuan dalam mencari peluang kemungkinan untuk memperoleh keuntungan, dan kemampuan untuk menilai situasi resiko secara realistis. Seorang wirausaha harus memiliki sifat kepemimpinan, kepeloporan, dan keteladanan. Wirausaha selalu menampilkan produk dan jasa-jasa baru dan berbeda, sehingga ia menjadi pelopor, baik dalam proses produksi maupun pemasaran, dan selalu memanfaatkan perbedaan sebagai sesuatu yang menambah nilai.

Wirausaha juga harus memiliki perspektif dan pandangan ke masa depan dengan kemampuan untuk menciptakan sesuatu yang baru dan berbeda. Penciptaan sesuatu yang baru dan berbeda tersebut dapat dilakukan dengan kreativitas dan inovasi yang dimiliki wirausahawan. Seorang wirausaha yang kreatif dan inovasi adalah orang yang (a) tidak pernah puas dengan caracara yang dilakukan saat ini meskipun cara tersebut cukup baik, (b) selalu menuangkan imajenasi dalam pekerjaannya, dan (c) selalu ingin tampil berbeda atau selalu memanfaatkan perbedaan.

Berdasarkan pendapat beberapa ahli, sifat-sifat yang harus dimiliki oleh seorang wirausaha adalah berani dalam mengambil langkah dan keputusan, jujur, tekun, ulet, sabar, tabah, positive thinking, rendah hati, kemauan dengan 
daya juang yang tinggi, bertanggungjawab, percaya diri, berani mengambil resiko, memiliki visi untuk masa depan, berjiwa kepemimpinan, dan keorisinalitasan yang meliputi kreativitas dan inovasi.

\section{Strategi Prodi dalam Mengembangkan Minat Mahasiswa Berwirausaha}

Program pengembangan jiwa kewirausahaan telah dicanangkan oleh Presiden Republik Indonesia pada bulan Juli 1995. Setelah itu diluncurkan berbagai program rintisan pengembangan jiwa kewirausahaan di kalangan mahasiswa. Program Kreativitas Mahasiswa (PKM), KKN-Usaha dan Cooperative Education (Co-op) yang diluncurkan beberapa saat setelah pencanangan Presiden tersebut, telah banyak menghasilkan alumni yang terbukti lebih kompetitif di dunia kerja. Hasil-hasil karya inovasi mahasiswa melalui PKM potensial tersebut ditindaklanjuti secara komersial menjadi sebuah embrio bisnis berbasis Ilmu Pengetahuan, Teknologi dan Seni (Ipteks).

Usaha dalam menanamkan jiwa dan semangat kewirausahaan bagi mahasiswa di perguruan tinggi harus terus digalakkan dan ditingkatkan, tentunya dengan berbagai metode dan strategi yang membuat mahasiswa tertarik untuk berwirausaha. Ada beberapa strategi yang dapat ditempuh oleh Prodi Manajemen Keuangan Syariah dalam meningkatkan minat mahasiswa sebagai calon wirausaha baru, diantaranya yaitu:

\section{a. Menyediakan Dosen yang Konsen dan Memiliki Jiwa Wirausaha}

Selama ini penyediaan dosen hanya sebatas pada linearitas keilmuan yang dimiliki dengan program studi yang ada di perguruan tinggi tersebut. Sehingga tidak menutup kemungkinan dalam proses pembelajaran nilai-nilai jiwa wirausaha belum tergambar dan terwujud dalam prakteknya. 
Setidaknya selain linearitas dalam menyiapkan dosen atau tenaga pendidik, perguruan tinggi harus mempersiapkan tenaga pendidik atau dosen yang mampu melakukan hal-hal sebagai berikut, yaitu:

1. Memberikan paradigma baru tentang pentingnya kewirausahaan.

2. Menginspirasi dan memotivasi mahasiswa menjadi SDM yang mandiri.

3. Merubah dan mengarahkan pola pikir mahasiswa menjadi seorang yang berjiwa wirausaha.

4. Memberikan contoh karya nyata kewirausahaan dan menyuguhkan cerita sukses.

5. Menghasilkan mahasiswa atau alumni menjadi seorang wirausaha sukses.

Program peningkatan dosen sebagai tenaga pendidik ini dapat dilakukan dengan melalui berbagai cara, diantaranya sebagai berikut:

1. Program pelatihan kewirausahaan untuk tenaga pendidik.

2. Program seminar, workshop, lokakarya kewirausahaan.

3. Program pemagangan dosen di dunia usaha.

4. Program sarasehan dengan mitra usaha.

5. Program pembinaan dan pendampingan dosen baru.

Dengan program tersebut, tentunya setiap dosen tidak hanya sekedar mengajar kewirausahaan saja, tetapi mampu mewujudkan dan merealisasikan apa yang telah diberikan kepada mahasiswa pada saat mengajar.

\section{b. Mengembangkan Kurikulum Berbasis Wirausaha}

Merumuskan sistem atau metode pembelajaran dan pelatihan kewirausahaan, perguruan tinggi harus mendesign mata kuliah atau materi kewirausahaan untuk mahasiswanya disesuaikan dengan target yang akan dicapai. Diawali dari pembuatan konsep pembelajaran yang harus dipantau oleh bidang akademik, yaitu: silabus, satuan acara pengajaran (SAP), slide 
presentasi dan handout, modul teori, modul praktek, pembuatan buku panduan, sampai pada program kunjungan dan pengamatan langsung ke tempat usaha yang layak untuk dijadikan tempat observasi, dan lain-lain.

Rumusan tersebut harus dikerjakan oleh sebuah tim yang ahli di bidang keilmuannya. Hal yang perlu diperhatikan oleh perguruan tinggi dalam merumuskan kurikulum ini adalah harus memaksimalkan dalam mengikutsertakan akademisi dan pelaku usaha serta motivator wirausaha dalam team penyusun, sehingga mata kuliah atau materi yang diberikan lebih berkualitas. Ini penting dilakukan karena kolaborasi antara akademisi, praktisi dan motivator akan menghasilkan konsep dan gagasan kewirausahaan yang tepat dan sesuai untuk mahasiswa dari berbagai disiplin keilmuan. Menyusun kurikulum kewirausahaan, tidak serta merta menjadikan kewirausahaan sebagai mata kuliah tersendiri, namun akan lebih memberikan pengaruh yang besar jika muatan nilai-nilai kewirausahaan ini dimasukkan ke dalam setiap mata kuliah.

\section{c. Membentuk Program Mahasiswa Wirausaha (PMW)}

Kedudukan Program Mahasiwa Wirausaha (PMW) merupakan bagian dari sistem pendidikan di perguruan tinggi yang telah diluncurkan semenjak tahun 2009. Dalam pelaksanaannya, PMW terintegrasi dengan pendidikan kewirausahaan (enterpreneur) yang sudah ada, antara lain dengan Program Kreativitas Mahasiswa (PKM), Kuliah Kerja Usaha (KKU) dan program kewirausahaan lain.

Tujuan penyelenggaraan PMW dimaksudkan untuk: 1) menumbuhkan motivasi berwirausaha di kalangan mahasiswa; 2) membangun sikap mental wirausaha, yakni: percaya diri, sadar akan jati dirinya, bermotivasi untuk meraih suatu cita-cita, pantang menyerah, mampu bekerja keras, kreatif, inovatif, berani mengambil resiko dengan perhitungan, berprilaku pemimpin 
dan memiliki visi ke depan tanggap terhadap saran dan kritik, memiliki kemampuan empati dan keterampilan sosial; 3) meningkatkan kecakapan dan keterampilan para mahasiswa khususnya sense of business; 4) menumbuhkembangkan wirausaha-wirausaha baru yang berpendidikan tinggi; 5) menciptakan unit bisnis baru yang berbasis ilmu pengetahuan, teknologi dan seni; dan 6) membangun jejaring bisnis antarpelaku bisnis, khususnya antara wirausaha pemula dan pengusaha yang sudah mapan. Alokasi dana PMW tidak seluruhnya untuk modal mahasiswa.

Mekanisme pelaksana program PMW diawali dengan: 1) melakukan sosialisasi kepada para mahasiswa; 2) identifikasi dan seleksi mahasiswa; 3) pembekalan kewirausahaan; 4) penyusunan rencana bisnis sambil magang di UKM.

Selanjutnya untuk mendapatkan dukungan permodalan dalam rangka pendirian usaha baru mahasiswa wajib mengajukan rencana bisnis yang layak untuk diseleksi oleh "Tim Seleksi" yang terdiri atas unsur perbankan, UKM, dan perguruan tinggi pelaksana. Pengusaha dilibatkan secara aktif untuk memberikan bimbingan operasional kewirausahaan.

Keberadaan kelembagaan yang bertanggungjawab atas programprogram pendidikan kewirausahaan merupakan salah satu pertimbangan penting bagi Direktorat Jenderal Pendidikan Tinggi yang bersangkutan. Dalam usaha mewujudkan calon-calon pengusaha muda pemula, menumbukembangkan budaya kewirausahaan di perguruan tinggi dapat dimulai melalui program Kuliah Kewirausahaan/KWU (Siswo Wiratno). Selama program PMW berjalan, perguruan tinggi bekerja sama dengan para pengusaha, baik dengan UKM koperasi maupun perusahaan besar lainnya. Pengusaha dilibatkan secara aktif untuk memberikan bimbingan praktis kewirausahaan, dimulai dari pendidikan dan pelatihan, pemagangan, menyusun rencana bisnis, dan pendampingan secara terpadu. Oleh karena itu, 
perlu dihindari terjadinya persaingan yang tidak sehat di antara mahasiswa dan UKM pendamping. Sebaliknya, diperlukan adanya "sinergitas" antara jenis usaha yang dikembangkan mahasiswa dan jenis usaha yang dikembangkan oleh UKM pendamping.

Persyaratan utama untuk menjamin keberhasilan dan keberlanjutan PMW, perguruan tinggi pelaksana harus mempunyai lembaga yang memiliki tugas pokok dan fungsi sebagai pengelola (perencana, pengorganisasian, pelaksanaan, pengawasan dan pengevaluasian) serta pengembangan (penelitian dan pengembangan) program-program pendidikankewirausahaan bagi mahasiswa dan program lain yang terkait dengan hubungan antar lembaga. Lembaga yang dimaksud dapat bersifat formal struktural ataupun fungsional yang bertanggunjawab langsung kepada pimpinan perguruan tinggi (Siswo Wiratno : 2012).

\section{d. Membentuk Program Kuliah Kewirausahaan (KWU)}

Dalam usaha mewujudkan calon-calon pengusaha muda terdidik atau pengusaha muda pemula dan menumbuhkembangkan budaya kewirausahaan di perguruan tinggi dapat dimulai dengan program KWU dimaksudkan sebagai upaya memperkenalkan dunia kewirausahaan agar dapat menumbuhkembangkan jiwa kewirausahaan bagi kalangan mahasiswa. Di samping itu, KWU dilaksanakan untuk memberikan pengetahuan kewirausahaan, pengalihan pengalaman berwirausaha dan mendorong tumbuhnya motivasi berwirausaha sebagai bentuk kegiatan awal mahasiswa calon wirausahawan baru. Agar terjadi interaksi antar mahasiswa dari berbagai bidang studi dalam proses pembelajaran kewirausahaan, maka peserta KWU diharapkan berasal dari berbagai mahasiswa dari program studi/jurusan/fakultas lainnya. 
Dalam upaya mewujudkan program tersebut, setiap perguruan tinggi diharapkan mampu: 1) meningkatkan pemahaman dan penjiwaan kewirausahaan di kalangan mahasiswa agar mampu menjadi wirausahawan yang berwawasan jauh ke depan dan luas berbasis ilmu yang diperolehnya; 2) mengenal pola pikir wirausaha serta meningkatkan pemahaman manajemen (organisasi, produksi, keuangan dan pemasaran), dan 3) memperkenalkan cara melakukan akses informasi dan pasar serta teknologi, cara pembentukan kemitraan usaha, strategi dan etika bisnis, serta pembuatan rencana bisnis atau studi kelayakan yang diperlukan mahasiswa agar lebih siap dalam pengelolaan usaha yang sedang akan dilaksanakan (Bambang Banu Siswoyo).

\section{e. Membentuk Klinik Konsultasi Bisnis dan Penempatan (Job-Placement Centre )}

Konsultasi Bisnis dan Penempatan Kerja (KBPK) yang dikembangkan dari Pusat Konsultasi bagi pengusaha kecil dan menengah merupakan salah satu kegiatan yang dapat memberikan pelayanan kepada alumni perguruan tinggi yang berminat menjadi pengusaha baru, atau pengusaha kecil yang telah berkecimpung dalam dunia usaha. KBPK mendidik staf pengajar memperoleh pengalaman dalam dunia usaha dengan cara memberikan konsultasi kepada pengusaha kecil dan menengah. KBKP juga membuka akses unuk sumber daya bahan baku, pasar, sumber daya informasi, serta membangun jaringan kerja untuk meningkatkan sinergi antar pengusaha kecil dan menengah.

\section{f. Membentuk Program Magang Kewirausahaan (MKU)}

Program “magang kewirausahaan” merupakan kegiatan mahasiswa untuk belajar bekerja secara nyata (praktek) pada usaha kecil menengah, yang diharapkan dapat menjadi wahana penumbuhan jiwa kewirausahaan. Magang merupakan salah satu cara mempersiapkan diri untuk menjadi wirausaha. 
Selama magang mahasiswa bekerja sebagai tenaga kerja di perusahaan mitra, sehingga mampu menyerap berbagai pengalaman praktik, seperti: 1) memahami proses produksi yang dihasilkan secara utuh; 2) mengenai metode yang dilakukan baik dari aspek teknologi maupun organisasi; 3) mengenal pasar dari produk yang dihasilkan; 4) memahami permasalahan yang dihadapi dan cara mengatasi permasalahan yang dihadapi dan cara mengatasi permasalahan; dan 5) berkembangnya sifat kreatif dan inovatif mahasiswa untuk bergerak di bidang wirausaha.

Magang kewirausahaan dilaksanakan untuk memberikan pengalaman praktis kewirausahaan kepada mahasiswa dengan cara ikut bekerja sehari-hari pada usaha kecil dan menengah. Secara khusus tujuan MKU: 1) meningkatkan kemampuan untuk menerapkan pengetahuan dan keterampilan yang dimiliki; 2) meningkatkan pengetahuan kewirausahaan mahasiswa, baik dalam hal keilmuan maupun pengalaman berwirausaha; 3) meningkatkan kemampuan berkomunikasi dan bersosialisasi dengan kalangan masyarakat di perusahaan; 4) memacu motivasi kewirausahaan mahasiswa yang berminat menjadi calon pengusaha; 5) membuka peluang untuk memperoleh pengalaman praktis kewirausahaan bagi dosen pembimbing mahasiswa; dan 6) menciptakan keterkaitan dan kesepadanan antara perguruan tinggi dengan usaha kecil dan menengah.

Lebih lanjut, kegiatan MKU dilaksanakan dalam lingkup: 1) penetapan usaha kecil menengah yang layak untuk tempat magang (perusahaan mitra); 2) pembekalan magang mahasiswa oleh dosen pembimbing; 3) temu gagasan antara perguruan tinggi dengan pimpinan perusahaan mitra; 4) pelaksanaan MKU; 5) pemantauan dan pembimbingan oleh dosen pembimbing dan perusahaan tempat magang; 6) evaluasi pelaksanaan magang oleh mahasiswa, pengusa dan dosen pembimbing; 7) penyusunan business plan oleh mahasiswa peserta magang; dan 8) penulisan laporan magang oleh 
mahasiswa; dan 9) pembahasan hasil magang yang diikuti semua pihak yang terkait.

Beberapa indikator pelaksanaan MKU dikatakan berhasil manakala: 1) pengusaha tempat magang merasakan manfaat MKU; 2) mahasiswa memperoleh pengetahuan, kompetensi dan pengalaman serta manfaat, baik dari segi pengetahuan maupun keterampilan yang berguna sebagai bekal untuk berwirausaha; dan 3) mahasiswa menjalankan tugas dengan disiplin dan mematuhi aturan perusahaan yang berlaku (Siswo Wiratno).

\section{Program Kuliah kerja Usaha (KKU)}

Untuk menjadi wirausahawan, mahasiswa perlu dibekali kemampuan praktis yang mencakup keterampilan menerapkan Iptek, keterampilan manajerial wirausaha dan pemasaran serta adopsi inovasi teknologi. Pengalaman ini dapat diperoleh mahasiswa melalui Kuliah Kerja Usaha (KKU), di mana kemampuan praktis ditumbuhkembangkan dengan berperan aktif, antara lain membantu usaha rumah tangga atau usaha kecil menengah tempat mahasiswa bermitra. Oleh karena itu, kegiatan KKU, diharapkan dapat menumbuhkembangkan calon wirausahawan yang handal dan mandiri dari kalangan mahasiswa melalui proses aktif yang berprinsip pada keberpihakan dan pemberdayaan masyarakat dalam rangka mendorong peningkatan pertumbuhan usaha kecil menengah.

Tujuan khusus yang ingin dicapai dari KKU, yaitu: 1) berkembangnya budaya kewirausahaan di perguruan tinggi; 2) terwujudnya calon sarjana yang cendikiawan dan berjiwa kewirausahaan serta sadar dengan masalah lingkungannya; dan 3) menumbuhkembangkan usaha kecil menengah yang memiliki daya saing tinggi dari segi kualitas produk/jasa, kinerja dan pemasaran. 
Mahasiswa yang melaksanakan KKU, selain belajar berwirausaha, juga menerapkan Iptek yang dikuasai, seperti penyempurnaan proses produksi, peningkatan kualitas produk dan jasa, penyempurnaan manajemen usaha, maupun pembenahan metode penasaran. Sambil membantu menata proses produksi atau pemasaran produk. Di samping itu, mahasiswa belajar bagaimana cara berkomunikasi dengan mitra bisnisnya (pengusaha, pegawai, konsumen, tengkulak, penjual eceran dan grosir), sehingga mendorong tumbuhnya kedewasaan berpikir, berkomunikasi dan bertindak.

\section{g. Inkubator Wirausaha Baru (INWUB)}

Inkubator Wira usaha Baru (INWUB) adalah suatu fasilitas fisik yang dikelola oleh sjumlah staf dan menawarkan suatu paket terpadu kepada alumni perguruan tinggi yang berminat menjadi wirausahawan dengan biaya terjangkau selama jangka waktu tertentu (2-3 tahun). Paket terpadu tersebut, antara lain meliputi: 1) sarana fisik atau ruang produksi dan fasilitas kantor yang dapat disepakati bersama; 2) kesempatan akses dan pembentukan jaringan kerja dengan jasa pendukung teknologi dan bisnis, sumberdaya teknologi dan informasi, sumber daya bahan baku dan keuangan; 3) pelayanan konsultasi yang meliputi aspek teknologi, manajemen dan pemasaran; 4) pembentukan jaringan kerja antar pengusaha, dan 5) pengembangan produk penelitian untuk dapat diproduksi secara komersial.

Tujuan dibentuknya INWUB yaitu untuk: 1) menciptakan lapangan kerja baru sehingga meningkatkan standar hidup golongan ekonomi lemah; 2) menciptakan UKM yang mandiri dan berlandaskan Iptek untuk memperkuat struktur ekonomi nasional; 3) membantu alih teknologi dari teknologi konvensional ke teknologi mutakhir (state of the art technology) yang tepat guna termasuk teknologi hasil putaran (spin off) industri besar, perguruan tinggi atau lembaga penelitian; dan 4) mempercepat perkembangan kewirausahaan di Indonesia untuk mencapai pengembangan ketahanan 
ekonomi yang berkelanjutan dalam menghadapi era perdagangan bebas (Siswo Wiratno).

\section{h. Kegiatan Karya Alternatif Mahasiswa}

Dalam berwira usaha produk/komoditi yang diperdagangkan adalah inti dari denyut perdagangan adalah inti dari denyut perdagangan itu sendiri. Setiap produk sejenis akan bersaing dalam kualitas yang meliputi untuk kerja, keandalan (reability) dan kekuatan (robustness) serta kemudahan pengoperasiannya (user friendly). Persaingan tersebut pada hakekatnya adalah persaingan teknologi yang diterapkan dalam kemasan yang menarik serta harga yang lebih murah sebagai hasil penelitian dan pengembangan.

Melalui kegiatan Karya Alternatif Mahasiswa (KAM) para mahasiswa telah mempelajari ilmu pengetahuan dan teknologi dilatih dan didorong untuk menghasilkan suatu komoditi yang diperlukan masyarakat. Prinsip yang perlu ditekankan dalam hal ini adalah bahwa keterampilan menghasilkan produk harus dipadukan dengan pemahaman bisnis yang minimal telah dimiliki mahasiswa pesertanya. KAM diprioritaskan untuk diisi dengan aktivitas produktif mahasiswa yang berpola khusus, sebagai bagian integral dari kegiatan intra atau ekstra kurikuler mahasiswa dalam usaha untuk membekalinya dengan keterampilan menghasilkan produk dan pengetahuan tentang bisnis rintisan (Bambang Banu Siswoyo).

\section{i. Menjalin Kerjasama dengan Lembaga Usaha}

Kerja sama ini penting dilakukan oleh perguruan tinggi, dengan adanya kerja sama akan meningkatkan kualitas dosen dan mahasiswa, memberikan kesempatan magang usaha bagi dosen dan mahasiswa, serta memberikan kesempatan kerja sama usaha khususnya untuk alumni. Sehingga mahasiswa dapat menganalisa dan mengamati bentuk usaha nyata yang pada akhirnya 
akan mempunyai gambaran ketika lulus dan berencana mewujudkan keinginan berwirausaha.

\section{j. Menjalin Kerjasama dengan Lembaga Keuangan}

Mewujudkan mahasiswa atau alumi sebagai seorang wirausaha, perguruan tinggi harus memberikan fasilitas dan kemudahan bagi mahasiswanya dalam membuka usaha. Salah satunya dengan cara menjadi fasilitator dan mediator antara mahasiswa dengan lembaga keuangan dalam hal kemudahan kredit usaha bagi mahasiswa ketika berkeinginan untuk melakukan wirausaha. Kerjasama ini dapat menjadi kesempatan bagi mahasiswa untuk mewujudkan menjadi wirausahawan muda. Pada umumnya mahasiswa ketika memiliki keinginan untuk berwirausaha terkendala dengan modal dana. Kerjasama inilah yang harus dilakukan oleh perguruan tinggi.

\section{k. Membuat Kebijakan Harus Sudah Memiliki Usaha Sebagai Syarat Kelulusan Mahasiswa}

Salah satu pemicu meningkatnya semangat kewirausahaan dari mahasiswa adalah dengan dibuatnya kebijakan syarat kelulusan, selain masa studi, indeks preastasi, dan syarat-syarat lain. Syarat harus sudah memiliki usaha sepertinya layak untuk diterapkan oleh perguruan tinggi

Dari beberapa strategi tersebut, jika diimplementasikan oleh perguruan tinggi dengan serius dan sungguh-sungguh maka dapat dimungkinkan akan banyak muncul wirausahawan sukses yang berasal dari tenaga muda terdidik di negeri ini yang dapat berperan dalam meningkatkan ekonomi kerakyatan dan pergerakan aktivitas ekonomi lokal sehingga akan terbentuk peluang dan kesempatan pekerjaan yang pada akhirnya akan mengurangi jumlah pengangguran. 


\section{SIMPULAN}

Prodi Manajemen Keuangan Syariah diharapkan mampu memfasilitasi dan melatih serta memotivasi mahasiswa sehingga menjadi generasi yang cerdas, mandiri, kreatif, inovatif dan mampu membuat berbagai peluang usaha. Maka dari itu, setiap perguruan tinggi segera menyeimbangkan arah kebijakan perguruan tingginya antara lembaga riset pendidikan tinggi dengan lembaga pembentuk pengusaha. Membentuk wirausaha muda diperlukan kesungguhan dan keseriusan dari perguruan tinggi khususnya Prodi Hukum Ekonomi Syariah (Muamalah) dalam melahirkan wirausaha muda dan terdidik.

\section{DAFTAR KEPUSTAKAAN}

Kasmir. 2011. Kewirausahaan. Jakarta: RajaGrafindo Persada.

Kompas.com. 14 September 2009

Suryana, Yuyus \& Kartib Bayu. 2013. Kewirausahaan: Pendekatan Karakteristik Wirausahawan Sukses, Jakarta: Kencana.

Saiman, Leonardo. 2014. Kewirausahaan Teori, Praktik, dan Kasus-kasus, Jakarta: Salemba Empat.

Saiman, Leonardo \&Bambang Banu Siswoyo, 2014.Pengembangan Jiwa Kewirausahaan di Kalangan Dosen dan Mahasiswa, Jurnal Ekonomi Bisnis.

Suryana. 2014. Kewirausahaan: Kiat dan Proses Menuju Sukses. Jakarta: Salemba Empat.

Wiratno, Siswo 2012. Pelaksanaan Pendidikan Kewirausahaan di Pendidikan Tinggi (The Implementation of Enterpreneurship Education in the Higher Education), Makalah Tahun 2012 